Research

\title{
Application of serum proteomics to the Women's Health Initiative conjugated equine estrogens trial reveals a multitude of effects relevant to clinical findings

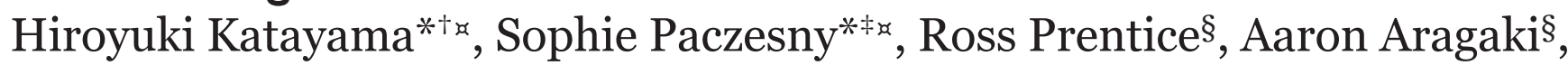 Vitor M Faca*, Sharon J Pitteri*, Qing Zhang*, Hong Wang*, Melissa Silva*, Jacob Kennedy*, Jacques Rossouw", Rebecca Jackson ${ }^{¥}$, Judith Hsia\#, Rowan Chlebowski** ${ }^{* *}$ JoAnn Manson ${ }^{\dagger \dagger}$ and Samir Hanash*
}

\begin{abstract}
Addresses: *Molecular Diagnostics Program, Fred Hutchinson Cancer Research Center, Fairview Avenue North, Seattle, WA 98109, USA. ${ }^{\dagger}$ Laboratory of Core Technology, Eisai Co. Ltd, 5-1-3 Tokodai, Tsukuba, Ibaraki 300-2635, Japan. "Department of Pediatrics, University of Michigan, Cancer Center, 1500 E. Medical Center Drive, Ann Arbor, MI 48109, USA. \$Public Health Sciences Division, Fred Hutchinson Cancer Research Center, Fairview Avenue North, Seattle, WA 98109, USA. "Women's Health Initiative Branch, National Heart, Lung, and Blood Institute, Rockledge Dr., Bethesda, MD 20892, USA. ${ }^{\ddagger}$ Division of Endocrinology, Ohio State University, Dodd Dr., Columbus, OH 43210, USA. \#AstraZeneca LP, Concord Pike, Wilmington, DE 29850, USA. ** Los Angeles Biomedical Research Institute at Harbor-UCLA Medical Center, W. Carson Street, Torrance, CA 90502, USA. ${ }^{\dagger \dagger}$ Brigham and Women’s Hospital, Harvard Medical School, Boylston Street, Boston, MA 02215, USA.
\end{abstract}

${ }^{x}$ These authors contributed equally to this work.

Correspondence: Samir Hanash. Email: shanash@fhcrc.org

Published: 29 April 2009

Genome Medicine 2009, I:47 (doi:10.1 186/gm47)

The electronic version of this article is the complete one and can be found online at http://genomemedicine.com/content///4/47

(c) 2009 Katayama et al.; licensee BioMed Central Ltd.

This is an Open Access article distributed under the terms of the Creative Commons Attribution License (http://creativecommons.org/licenses/by/2.0), which permits unrestricted use, distribution, and reproduction in any medium, provided the original work is properly cited.

Received: 15 January 2009

Revised: 29 March 2009

Accepted: 29 April 2009

\begin{abstract}
Background: The availability of serum collections from the Women's Health Initiative (WHI) conjugated equine estrogens (CEE) randomized controlled trial provides an opportunity to test the potential of in-depth quantitative proteomics to uncover changes in the serum proteome related to CEE and to assess their relevance to trial findings, including elevations in the risk of stroke and venous thromboembolism and a reduction in fractures.
\end{abstract}

Methods: Five independent large scale quantitative proteomics analyses were performed, each comparing a set of pooled serum samples collected from 10 subjects, I year following initiation of CEE at $0.625 \mathrm{mg} / \mathrm{d}$, relative to their baseline pool. A subset of proteins that exhibited increased levels with CEE by quantitative proteomics was selected for validation studies.

Results: Of $61 \mathrm{I}$ proteins quantified based on differential stable isotope labeling, the levels of 116 (19\%) were changed after I year of CEE (nominal $P<0.05$ ), while 64 of these had estimated false discovery rates $<0.05$. Most of the changed proteins were not previously known to be affected by CEE and had relevance to processes that included coagulation, metabolism, osteogenesis, inflammation, and blood pressure maintenance. To validate quantitative proteomic data, 14 proteins were selected for ELISA. Findings for ten - IGFI, IGFBP4, IGFBPI, IGFBP2, FI0, AHSG, GC, CP, MMP2, and PROZ - were confirmed in the initial set of 50 subjects and further validated in an independent set of 50 additional subjects who received CEE. 


\begin{abstract}
Conclusions: CEE affected a substantial fraction of the serum proteome, including proteins with
\end{abstract} relevance to findings from the WHI CEE trial related to cardiovascular disease and fracture.

\title{
Clinical Trials Registration: ClinicalTrials.gov identifier: NCT000006 I I
}

\section{Background}

Estrogens exert effects on target genes in various tissues through complex processes [1]. Given the widespread use of conjugated equine estrogens (CEE) and other estrogens for menopausal symptoms, the issue of overall health benefits and risks associated with CEE has been a major research focus. For example, recommendations for use of estrogen for prevention of coronary heart disease (CHD) were based on epidemiologic, animal, and laboratory data [2,3]. However, the Women's Health Initiative (WHI) randomized, placebo controlled trial of $0.625 \mathrm{mg} / \mathrm{d}$ continuous CEE among 10,739 women who were post-hysterectomy did not provide evidence of benefit for CHD, and health benefits and risks appeared to be approximately balanced [4]. It has been suggested that women who started CEE earlier after menopause could be at lower risk of CHD, but not stroke, than women who initiated hormone therapy more distant from the menopause [5-8]. Demonstrated benefits of CEE include improvement of vasomotor symptoms [9] and prevention of osteoporotic fractures, in particular reduction in hip fractures $[10,11]$. Adverse effects observed in the WHI trial include increased incidence of venous thromboembolism and stroke $[4,12,13]$.

Recent studies, including the WHI trials, have shown that estrogen therapy (ET) induced changes in several proteins and metabolites, including decreases in low-density lipoprotein cholesterol and increases in high-density lipoprotein cholesterol and triglycerides; decreases in fasting glucose, insulin, and homocysteine; increases in C-reactive protein, matrix metalloproteinase- 9 and plasmin-antiplasmin complex; and decreases in E-selectin and plasmin activator inhibitor [14]. Other studies have documented increases in angiotensinogen and its product angiotensin II, a potent vasoconstrictor, and suppression of active renin with postmenopausal ET $[15,16]$. There is also some evidence of an effect on insulin-like growth factor (IGF) and IGF binding proteins (IGFBPs) in postmenopausal women [17,18]. Given these diverse effects, an unbiased comprehensive profiling of serum to assess the effect of CEE is warranted. However, such comprehensive quantitative proteomic profiling in the context of a clinical trial has not been done previously. Thus, it was of interest to determine whether proteomic profiling would uncover protein changes that have relevance to WHI CEE trial findings.

We have applied an intact protein analysis system (IPAS) approach that allows identification of proteins over seven orders of magnitude of abundance to determine the effect of oral CEE on the serum proteome [19-22]. A prior proteomic study of hormone therapy-relevant samples [23] relied on a fingerprinting approach with limited sensitivity and without protein identification. In this study we present a systematic global proteome analysis of sera obtained at baseline and after 1 year of oral ET from 50 postmenopausal women. We have validated quantitative proteomic data for a subset of proteins by enzyme-linked immunosorbent assay (ELISA) with sera from the initial set of 50 subjects and with sera from an independent set of 50 randomly selected subjects who adhered to CEE and that were obtained at baseline and after 1 year of oral ET.

\section{Methods \\ Study design}

Use of human samples was approved by the Fred Hutchinson Cancer Research Center Institutional Review Board. For the discovery phase of this study, 50 subjects were randomly selected from women in the WHI trial who received and adhered to oral CEE $0.625 \mathrm{mg}$ daily over the first year from randomization, and who did not experience a major clinical outcome during trial follow-up. This population is a substudy of the WHI CEE trial, which is composed of 10,739 women, 5,310 in the active CEE arm and 5,429 in the placebo arm. These women had each undergone hysterectomy, and most had never received hormone therapy prior to trial enrollment. Some were prior postmenopausal hormone therapy users who had stopped hormone therapy some months or years prior to trial enrollment. Rarely, subjects were current hormone therapy users at baseline screening and these subjects were required to undergo a 3 month 'wash-out' period of no hormone therapy use prior to randomization. Sera were collected before and after 1 year of CEE in $7 \mathrm{ml}$ royal blue-stoppered serum tubes for trace elements, no additive, silicone coated (BD 367737), and frozen at $-80^{\circ} \mathrm{C}$ until proteomic analysis. All subjects in this substudy were adherent to study medication (defined as taking $>80 \%$ of study medication per protocol) throughout the first year from randomization. Sera from a second subgroup $(n=50)$ of women from the active CEE arm of the CEE trial who met the same selection criteria were included in an independent sample ELISA validation phase of this study.

\section{Sample preparation}

Sera samples at baseline and 1 year after ET (50 women total) were divided in 5 experiments. For each experiment $30 \mu \mathrm{l}$ aliquots of sera from 10 women at baseline, and 
10 women 1 year after ET were pooled. Baseline and treated pools were then individually immunodepleted of the top six most abundant proteins (albumin, IgG, IgA, transferrin, haptoglobin and antitrypsin) using a Hu-6 column $(4.6 \times 250 \mathrm{~mm}$; Agilent, Wilmington, DE, USA). Briefly, columns were equilibrated with buffer $\mathrm{A}$ at $0.5 \mathrm{ml} /$ minutes for 13 minutes and aliquots of $75 \mu \mathrm{l}$ of the pooled sera were injected after filtration through a $0.22 \mu \mathrm{m}$ syringe filter. The flow-through fractions were collected for 10 minutes at a flow rate of buffer A of $0.5 \mathrm{ml} /$ minute, combined and stored at $-80^{\circ} \mathrm{C}$ until use. The column bound material was recovered by elution for 8 minutes with buffer $B$ at $1 \mathrm{ml} /$ minute. Subsequently, immunodepleted samples were concentrated using Centricon YM-3 devices (Millipore, Billerica, MA, USA) and re-diluted in $8 \mathrm{M}$ urea, $30 \mathrm{mM}$ Tris pH 8.5, 0.5\% OG (octyl-beta-d-glucopyranoside; Roche Diagnostics, Indianapolis, IN, USA). Samples were reduced with DTT in $50 \mu \mathrm{l}$ of $2 \mathrm{M}$ Tris-HCl pH 8.5 (o.66 mg DTT/mg protein), and isotopic labeling of intact proteins in cysteine residues were performed with acrylamide. Baseline pools received the light acrylamide isotope (C12 acrylamide; $>99.5 \%$ purity; Sigma-Aldrich (Fluka), St. Louis, MO, USA), and their corresponding 1 year ET pools received the heavy 1,2,3-C13-acrylamide isotope ( $\mathrm{C} 13$ acrylamide; >98\% purity; Cambridge Isotope Laboratories, Andover, MA, USA). Alkylation with acrylamide was performed for $1 \mathrm{~h}$ at room temperature by adding to the protein solution the appropriate quantity of C12-acrylamide or C13-acrylamide per milligram protein, diluted in a small volume of $2 \mathrm{M}$ Tris- $\mathrm{HCl}$ pH 8.5 [19]. For each of the five experiments, the pool of baseline (C12) and estrogen-treated (C13) samples was then mixed together for further analysis.

\section{Protein fractionation}

The two-dimensional protein fractionation has been performed based on the previously described IPAS approach $[20,22,24]$. Briefly, after isotopic labeling and mixing of the two pools, the sample was diluted to $10 \mathrm{ml}$ with $20 \mathrm{mM}$ Tris in 6\% isopropanol, $4 \mathrm{M}$ urea $\mathrm{pH} 8.5$ and immediately injected in a Mono-Q 10/100 column (Amersham Biosciences, Piscataway, NJ, USA) for the anion-exchange chromatography, the first dimension of the protein fractionation. The buffer system consisted of solvent A (20 mM Tris in 6\% isopropanol, $4 \mathrm{M}$ urea $\mathrm{pH}$ 8.5) and solvent $\mathrm{B}$ (20 mM Tris in 6\% isopropanol, $4 \mathrm{M}$ urea, $1 \mathrm{M} \mathrm{NaCl} \mathrm{pH} \mathrm{8.5).} \mathrm{The} \mathrm{separation}$ was performed at $4.0 \mathrm{ml} /$ minutes in a gradient of $0-35 \%$ solvent B in 44 minutes; $35-50 \%$ solvent B in 3 minutes; $50-100 \%$ solvent B in 5 minutes; and $100 \%$ solvent B for an additional 5 minutes. A total of 12 pools were collected from the anion exchange chromatography. The 12 pools were then subjected to a second dimension of separation by reversedphase chromatography. The reversed-phase fractionation was carried out with a Poros R2 column $(4.6 \times 50 \mathrm{~mm}$; Applied Biosystems, Foster City, CA, USA) using trifluoroacetic acid/acetonitrile as buffer system (solvent A, 95\% $\mathrm{H}_{2} \mathrm{O}, 5 \%$ acetonitrile, $0.1 \%$ trifluoro-acetic acid; solvent $\mathrm{B}$,
90\% acetonitrile, $10 \% \mathrm{H}_{2} \mathrm{O}, 0.1 \%$ trifluoro-acetic acid) at $2.7 \mathrm{ml} /$ minutes. The gradient used was $5 \%$ solvent A until absorbance reached baseline (desalting step) and then 5-50\% solvent B in 18 minutes; 50-80\% solvent B in 7 minutes and $80-95 \%$ solvent B in 2 minutes. Sixty fractions of $900 \mu \mathrm{l}$ were collected during the run, corresponding to a total of 720 fractions for each experiment. Aliquots of $200 \mu \mathrm{l}$ of each fraction, corresponding to approximately $20 \mu \mathrm{g}$ of protein, were separated for mass-spectrometry shotgun analysis.

\section{Mass spectrometry analysis}

For protein identification we performed in-solution trypsin digestion with the lyophilized aliquots of the 720 individual fractions. Individual digested fractions 4 to 60 from each reversed-phase run were pooled in 11 pools, corresponding to a total of 132 fractions for analysis from each experiment. Tryptic peptides were analyzed by a LTQ-FT mass spectrometer (Thermo-Electron, Waltham, MA USA) coupled to a nano-Aquity nanoflow chromatography system (Waters, Milford, MA, USA). The liquid chromatography separation was performed in a $25 \mathrm{~cm}$ column (Picofrit $75 \mu \mathrm{m}$ ID; New Objective, Woburn, MA, USA), in-house-packed with MagicC18 (Michrom Bioresources, Auburn, CA, USA) resin using a 90 minutes linear gradient from $5-40 \%$ of acetonitrile in $0.1 \%$ formic acid at $250 \mathrm{nl} /$ minute. The spectra were acquired in a data-dependent mode in a $\mathrm{m} / \mathrm{z}$ range of 400 to 1,800 , and selection of the 5 most abundant +2 or +3 ions of each mass spectrometry (MS) spectrum for MS/MS analysis. Mass spectrometer parameters were: capillary voltage of $2.1 \mathrm{KV}$; capillary temperature of $200^{\circ} \mathrm{C}$; resolution of 100,000; and FT target value of 1,000,000.

\section{Protein identification}

The acquired LC-MS/MS data were automatically processed by the Computational Proteomics Analysis System (CPAS) [25]. For the identification of proteins with a false discovery rate $(\mathrm{FDR})<5 \%$, database searches were performed using $\mathrm{X}$ !Tandem against the human IPI (International Protein Index) database v.3.13 using tryptic search [25]. Cysteine alkylation with the light form of acrylamide was set as a fixed modification and with the heavy form of acrylamide $(+3.01884)$ as a variable modification. The database search results were then analyzed by PeptideProphet [26] and ProteinProphet [27] programs. Our high confidence list of identifications retained proteins with ProteinProphet scores $\geq 0.95$ ( $5 \%$ error rate) and two or more peptides per protein.

\section{Quantitative analysis of protein levels}

Quantitative ratios of proteins comparing 1-year to baseline samples were obtained by differential labeling of peptides containing cysteine with acrylamide isotopes (heavy or light). Quantitative information was extracted using a script designated 'Q3ProteinRatioParser' that was developed inhouse to obtain the relative quantification for each pair of peptides identified by MS/MS that contains cysteine residues [19]. Only peptides with a minimum PeptideProphet 
score of 0.75 , and mass deviation $<20$ ppm were considered for quantification. Ratios of heavy-to-light acrylamidelabeled peptides were plotted on a histogram (log2 scale) and the median of the distribution was centered at zero. This normalization approach was chosen since the great majority of proteins were not expected to be deregulated in 1-year ET compared to baseline samples. All normalized peptide ratios for a specific protein were averaged to compute an overall protein ratio. Proteins for which only peptides labeled with the heavy form of acrylamide were detected were included in the final list of proteins with quantitative information presented as '1-year ET only'. All peptide and protein ratios were calculated on a logarithmic scale. Statistical significance of the protein quantitative information was obtained via two procedures: for those proteins with multiple peptides quantified, a $P$-value for the mean log-ratio, which has mean zero under the null hypothesis, was calculated using onesample $t$-test; and for proteins with a single paired MS event, the probability for the ratio was extrapolated from the distribution of ratios in a baseline-baseline experiment whereby the same sample was labeled with heavy and light acrylamide. The raw data and summary list of identified and quantified proteins are available through the Computational Proteomics Analysis System upon request.

\section{Statistical comparison of five IPAS proteomics analyses}

Protein ratios were analyzed to identify proteins whose average ratio (1 year of CEE/baseline), averaged over the five proteomic experiments, differed from zero on a log2 scale. All analyses were performed using the statistical package $\mathrm{R}$ [28]. Protein log-ratios were normalized across experiments by a median location shift to ensure the distributions of proteins for each IPAS experiment were centered at zero. Protein log-ratios were standardized by forming a sample variance from the (up to five) log-ratios for each protein, and adding a corresponding sample variance from a corresponding set of (up to five) log-ratios from a completely analogous set of five proteomic experiments from the WHI estrogen plus progestin trial. Statistical testing was performed by using a weighted moderated t-statistic [29] implemented in the $\mathrm{R}$ package LIMMA [30]. A weighted average ratio was calculated for each protein by weighting the (up to five) log-ratios by the number of quantified peptides for each protein and a matrix of weights was included in the linear model. Benjamini and Hochberg's method for controlling the FDR was used to compute adjusted $P$-values [31].

To improve our estimate of the posterior standard deviation used in the moderated t-statistics, protein ratios from an additional five IPAS experiments that compare estrogen plus progestin and whose quantification followed exactly the same protocol were also included in the linear model. Specifically, average ratios were calculated by fitting a linear model where the design matrix consisted of two dummy variables indicating estrogen or estrogen plus progestin use.
All results in this manuscript are based on inferences for the dummy variable of estrogen use (that is, the average ratio for ET use). Including the estrogen plus progestin data does not affect the estimated values of the ET ratios, but does increase the degrees of freedom and consequently increases power.

\section{Networks analysis}

For network analysis, the unfiltered list of gene names of proteins, and their ratios and $P$-values from all five IPAS experiments were uploaded into the MetaCore analytical suite version 4.7 (GeneGO, Inc., St. Joseph, MI, USA), and analysis was performed as described previously [32].

\section{ELISA-based validation}

Measurements were performed on the same sera from the 50 women utilized for proteomic analysis using ELISAs according to the manufacturer's protocols: human IGFBP1, IGFBP2, IGFBP4, and IGFBP6 (R\&D Systems, Minneapolis, MN, USA); IGF1 (Diagnostic Systems Laboratories, Webster, TX, USA); factor IX (F9), factor X (F10), and PROZ (protein $\mathrm{Z}$, vitamin $\mathrm{K}$-dependent plasma glycoprotein) (Hyphen Biomed, Neuville-Sur-Oise, France); ceruloplasmin (US Biological, Swampscott, MA, USA); vitamin D binding protein (Alpco Diagnostics, Salem, NH, USA); fetuin-A (AHSG) (Biovendor, Candler, NC, USA); vitronectin (Innovative Research, Novi, MI, USA); KNG1 (Affinity Biologicals, Ancaster, ON, Canada); MMP2 (Calbiochem, Gibbstown, NJ, USA). Individual serum samples and standards were run in duplicate and absorbance measured using a SpectraMax Plus 384 and results calculated with SoftMax Pro v4.7.1 (Molecular Devices, Sunnyvale, CA, USA). $P$-values and testing whether there was a significant change from baseline to year 1 for individual proteins were computed using the non-parametric $t$-test on the log2 scale. For a particular protein, validity of IPAS results was gauged by comparing means (95\% confidence intervals) of protein ratios to results from standard ELISA kits. The t-statistic and moderated t-statistic were used to calculate $95 \%$ confidence intervals for ELISA and IPAS data. For comparison of discovery and validation findings we also report Pearson's correlation coefficients for log-ratios.

\section{Results \\ Proteomic analysis of sera from study subjects}

Some characteristics at baseline of the 50 subjects included in the discovery phase are summarized in Table 1 . There were no statistically significant differences in any baseline characteristics noted between pools. The average age of the subjects was $61.4 \pm 7.9$ years (mean \pm standard deviation).

There were 2,576,869 tandem mass spectra with >0.05 PeptideProphet score acquired in these experiments (Table 2); $1,760,094$ spectra yielded proteins identified with a $<5 \%$ error rate. To our knowledge, this serum protein dataset is the largest obtained from a human observational study or 
Table I

Overview of subject characteristics $(n=50)$

\begin{tabular}{|c|c|c|c|c|c|}
\hline & $\mathrm{N}$ & $\%$ & & $\mathrm{~N}$ & $\%$ \\
\hline \multicolumn{3}{|l|}{ Age group at screening, years } & \multicolumn{3}{|l|}{ Treated diabetes } \\
\hline $50-59$ & 25 & 50.0 & No & 43 & 86.0 \\
\hline $60-69$ & 13 & 26.0 & Yes & 7 & 14.0 \\
\hline \multirow[t]{2}{*}{$70-79$} & 12 & 24.0 & & & \\
\hline & & & \multicolumn{3}{|c|}{ Treated for hypertension or blood pressure $\geq 140 / 90 \mathrm{mmHg}$} \\
\hline \multicolumn{3}{|l|}{ Ethnicity } & No & 29 & 63.0 \\
\hline White & 42 & 84.0 & Yes & 17 & 37.0 \\
\hline Black & 5 & 10.0 & & & \\
\hline Hispanic & 3 & 6.0 & \multicolumn{3}{|l|}{ History of high cholesterol requiring pills } \\
\hline \multicolumn{3}{|l|}{ Hormone replacement therapy use } & No & 42 & 95.5 \\
\hline Never used & 26 & 52.0 & Yes & 2 & 4.5 \\
\hline Past user & 19 & 38.0 & & & \\
\hline \multirow[t]{2}{*}{ Current user } & 5 & 10.0 & Statin use at baseline & & \\
\hline & & & No & 48 & 96.0 \\
\hline \multicolumn{3}{|c|}{ Hormone replacement therapy duration, years } & Yes & 2 & 4.0 \\
\hline$<5$ & 16 & 66.7 & & & \\
\hline 5 to $<10$ & 3 & 12.5 & Aspirin ( $\geq 80 \mathrm{mg}$ ) use at baseline & & \\
\hline \multirow{2}{*}{$10+$} & 5 & 20.8 & No & 42 & 84.0 \\
\hline & 3 & & Yes & 8 & 16.0 \\
\hline \multicolumn{6}{|l|}{ Body mass index (BMI), kg/m² } \\
\hline$<25$ & 6 & 12.2 & History of myocardial infarction & & \\
\hline 25 to $<30$ & 18 & 36.7 & No & 50 & 100.0 \\
\hline$\geq 30$ & 25 & 51.0 & History of angina & & \\
\hline \multicolumn{3}{|l|}{ BMI at year I } & No & 47 & 94.0 \\
\hline$<25$ & 3 & 6.1 & Yes & 3 & 6.0 \\
\hline 25 to $<30$ & 21 & 42.9 & & & \\
\hline$\geq 30$ & 25 & 51.0 & $\begin{array}{l}\text { History of coronary artery bypass graft/pe } \\
\text { coronary angioplasty }\end{array}$ & ous & ninal \\
\hline \multicolumn{3}{|l|}{ Smoking } & No & 47 & 100.0 \\
\hline Never smoked & 29 & 58.0 & & & \\
\hline Past smoker & 19 & 38.0 & History of stroke & & \\
\hline Current smoker & 2 & 4.0 & No & 50 & 100.0 \\
\hline \multicolumn{3}{|l|}{ Parity } & \multicolumn{3}{|c|}{ History of deep vein thrombosis or pulmonary embolism } \\
\hline Never pregnant/no term pregnancy & 4 & 8.0 & No & 50 & 100.0 \\
\hline \multirow[t]{2}{*}{$\geq$ I term pregnancy } & 46 & 92.0 & 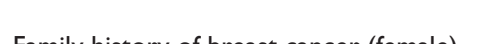 & & \\
\hline & & & Family history of breast cancer (female) & & \\
\hline \multicolumn{3}{|l|}{ Age at first birth, years } & No & $4 I$ & 85.4 \\
\hline$<20$ & 15 & 34.1 & Yes & 7 & 14.6 \\
\hline $20-29$ & 27 & 61.4 & & & \\
\hline \multirow{2}{*}{$30+$} & 2 & 4.5 & History of fracture on/after age 55 & & \\
\hline & & & No & 31 & 96.9 \\
\hline \multicolumn{3}{|l|}{ Age at hysterectomy, years } & Yes & I & 3.1 \\
\hline$<40$ & 19 & 38.0 & & & \\
\hline $40-49$ & 18 & 36.0 & Gail Model five year risk of breast cancer & & \\
\hline $50-54$ & 6 & 12.0 & $<1$ & 10 & 20.0 \\
\hline $55+$ & 7 & 14.0 & I to $<2$ & 34 & 68.0 \\
\hline & & & 2 to $<5$ & 6 & 12.0 \\
\hline Prior bilateral oophorectomy & & & Number of falls in last 12 months & & \\
\hline No & 33 & 71.7 & None & 30 & 69.8 \\
\hline Yes & 13 & 28.3 & 1 & 7 & 16.3 \\
\hline & & & 2 & 6 & 14.0 \\
\hline
\end{tabular}

clinical trial to date. This remarkable size of the serum protein dataset is a result of the extensive fractionation and large number of mass spectra collected in these experiments. The number of proteins identified and quantified showed some variation between experiments $(16 \%$ coefficient of variation for number of quantified proteins), which may be related to sample processing and MS sampling. However, this variation is not expected to affect quantitative ratios, as each experiment consisted of combined baseline and posttherapy sera that were differentially isotopically labeled 


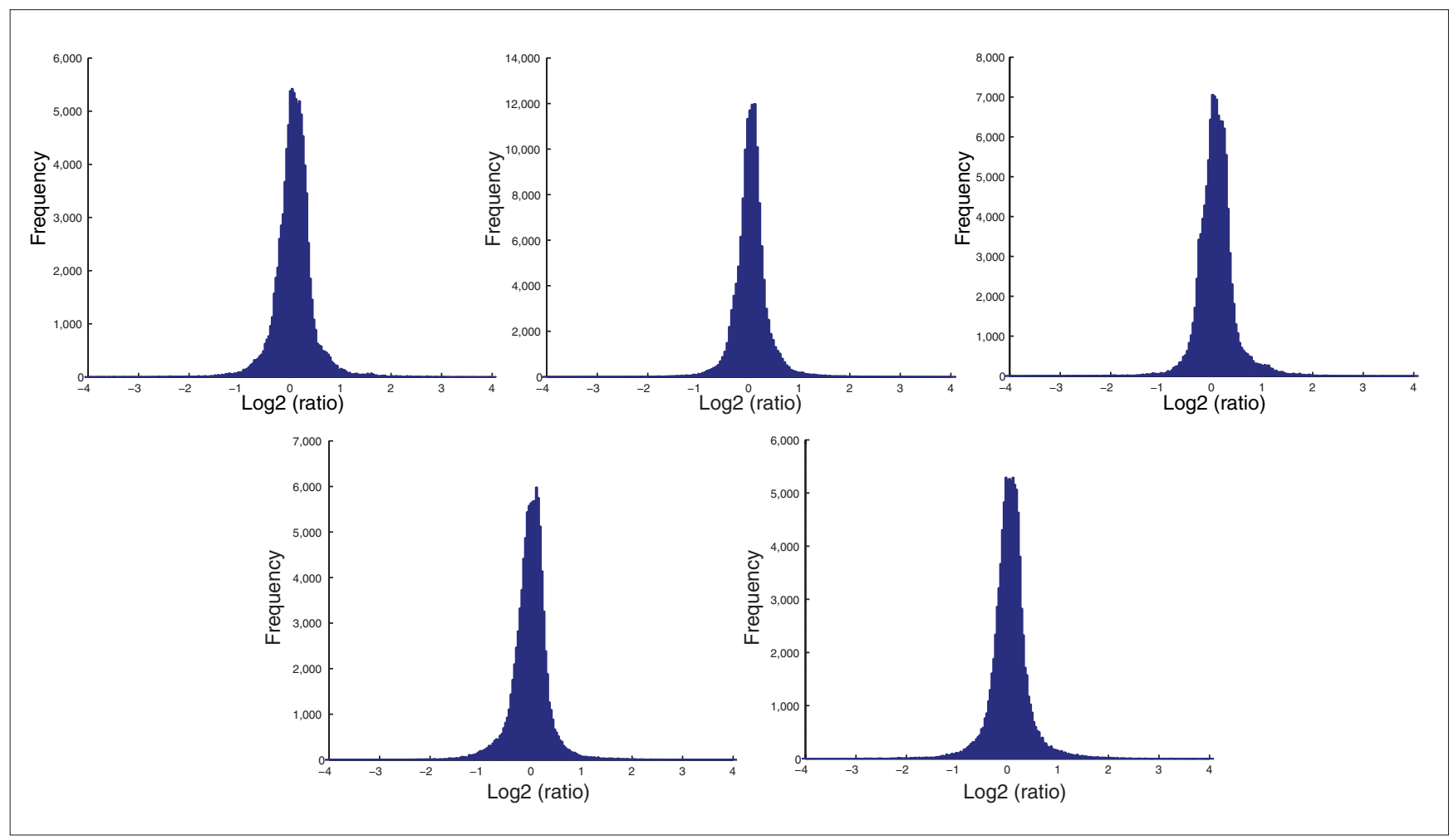

Figure I

Distribution of ratios for quantified peptides for the five IPAS experiments. A histogram of I-year CEE/baseline (log2) ratios as determined from heavyto-light isotopic labeling with acrylamide are shown for each IPAS experiment. The median of the distribution was centered at zero for normalization.

prior to mixing. Labeling efficiency was evaluated and the results are shown in Figure 1. The log-ratio histograms were all approximately Gaussian shaped.

\section{Changes observed at I year following ET relative to baseline} A list of weighted, quantified protein products of 611 distinct genes resulted from the serum proteomic analysis (Additional data file 1), after filtering protein identifications to remove proteins without associated gene name (hypothetical proteins) and false identifications based on manual verification of mass spectra. The $\log 2$ ratios of protein levels (1 year $\mathrm{CEE} /$ baseline), derived from the isotopic labeling of cysteine residues, and their $P$-values is provided as volcano plots (Figure 2a). We found that 116 of the 611 proteins quantified in the serum met a nominal 0.05 significance level criterion for change after 1 year of CEE, compared to about 31 expected by chance. A similar view was obtained when adjusted $P$-values (FDR <0.05) were considered (Figure 2b). We found that 64 of the 611 proteins quantified (10.5\%) in the serum had estimated FDRs of $P<0.05$ for change from

Table 2

Overview of proteomic analysis characteristics

\begin{tabular}{lccc}
\hline Experiment & $\begin{array}{c}\text { Number of tandem mass } \\
\text { spectra acquired }\end{array}$ & $\begin{array}{c}\text { Number of spectra that } \\
\text { yielded protein identifications with <5\% error rate }\end{array}$ & $\begin{array}{c}\text { Number of unique } \\
\text { proteins quantified }\end{array}$ \\
\hline 1 & 414,895 & 293,466 & 543 \\
2 & 584,525 & 403,189 & 574 \\
3 & 524,366 & 355,411 & 575 \\
4 & 573,327 & 381,057 & 530 \\
5 & 479,756 & 326,971 & 370 \\
Total & & & 1,056 \\
\hline
\end{tabular}



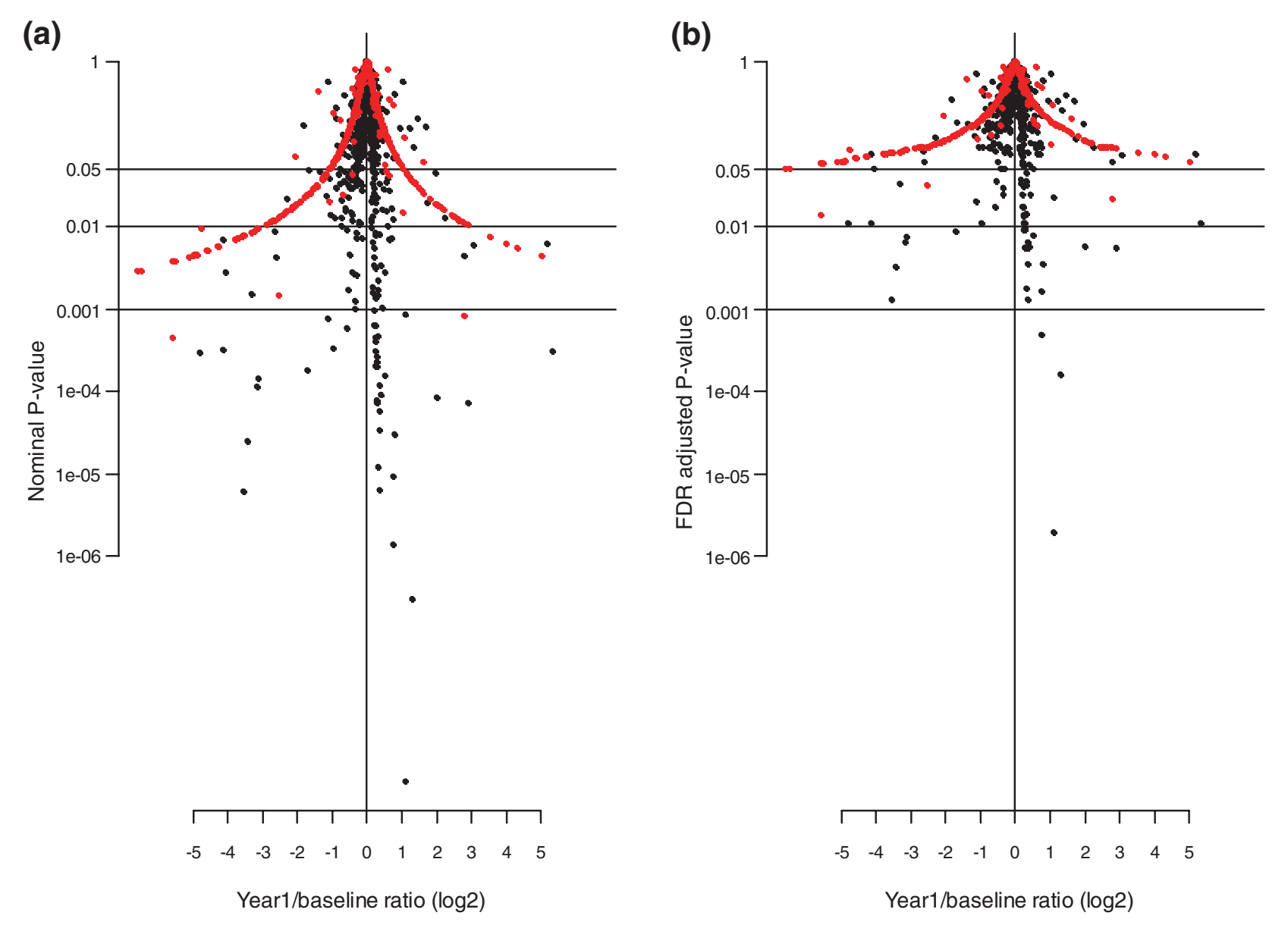

Figure 2

Volcano plots. (a) For nominal $P$-values. Relationship between the I-year ET/baseline log2 ratios and their $P$-values. (b) For FDR adjusted $P$-values. Relationship between the I year ET/baseline log2 ratios and their FDR adjusted $P$-values.

baseline to 1 year from randomization (Additional data file 2), while a strongly overlapping set of 64 proteins had nominal $P<0.05$ and also had estimated log-ratios $>1.20$ or $<1 / 1.20$ (Additional data file 3). A network analysis of the 64 proteins with statistically significant changes relative to all quantified proteins and with an FDR <0.05 (MetaCore version 4.7) [32-35] yielded a significant enrichment in five networks: blood coagulation, kallikrein-kinin system, cell adhesion-platelet-endothelium-leukocyte interactions, complement system, and ossification (Table 3). We further classified these 64 proteins in relation to the known biological processes they are involved in through a search of the Gene Ontology (GO) database (Table 4). A search of the literature yielded prior associations with ET for 13 of the 64 proteins (ceruloplasmin (CP), plasminogen (PLG), tissue factor pathway inhibitor (TFPI), sex hormone binding globulin (SHBG), IGFBP1, IBFBP4, apolipoprotein A-II (APOA2), vitamin D binding protein (GC), apolipoprotein D (APOD), IGF1, AHSG, lactotransferrin (LTF), angiotensinogen (AGT); Table 4).
Thus, novel associations were observed for 41 proteins. These proteins are associated primarily with blood coagulation, metabolism regulation, complement/inflammation/innate immunity, ossification, cellular growth, cell-cell/cell-matrix interactions, vessel morphogenesis/angiogenesis and blood pressure maintenance processes.

A critical step in estrogen effect on gene expression is recognition of the estrogen response elements (EREs) via estrogen receptors. For the differentially expressed proteins, we checked for the presence of conserved (between mouse and human) EREs in their corresponding genes. The sequence match was performed against a publicly available ERE database [36]. Four proteins - AGT, galectin-1 (LGALS1), LTF, and trefoil factor $3\left(\mathrm{TFF}_{3}\right)$ - found to be significantly elevated with CEE in our study, had conserved EREs upstream of the coding region. None of the down-regulated proteins had conserved EREs upstream of the coding regions of their genes. However, one down-regulated protein (matrix 
Table 3

Significant GeneGo biological networks for proteins that met a FDR $<0.05$

\begin{tabular}{|c|c|c|c|c|}
\hline $\begin{array}{l}\text { Network } \\
\text { number }\end{array}$ & Name & $P$-value & $\begin{array}{l}\text { Network } \\
\text { objects }\end{array}$ & Objects in the network* \\
\hline I & Blood coagulation & $1.66 \mathrm{e}-6$ & $7 / 83$ & $\begin{array}{l}\text { UP: FI2, F9, FI0, PROZ, SERPINGI, MSTI } \\
\text { DOWN: MMP2 }\end{array}$ \\
\hline 2 & Complement system & $1.57 \mathrm{e}-4$ & $5 / 73$ & $\begin{array}{l}\text { UP: SERPINGI, C2 (C2a, C2b) } \\
\text { DOWN: MBL2 }\end{array}$ \\
\hline 3 & Kallikrein-kinin system & 2.84 e-4 & $7 / 183$ & UP: PLG, SERPINGI, F9, FI0, FI2, HABP2 \\
\hline 4 & Cell adhesion, cell matrix interactions & 6.34 e-4 & $7 / 209$ & $\begin{array}{l}\text { UP: VTN, TGFBI, HABP2, LGALS3BP, LGALSI } \\
\text { DOWN: MMP2, COLIAI }\end{array}$ \\
\hline 5 & $\begin{array}{l}\text { Platelet-endothelium- } \\
\text { leukocyte interactions }\end{array}$ & 1.42 e-3 & $6 / 175$ & $\begin{array}{l}\text { UP: PLG, FI2, FI0, SERPINGI, VTN } \\
\text { DOWN: MMP2 }\end{array}$ \\
\hline 6 & Ossification & 4.34 e-3 & $5 / 152$ & $\begin{array}{l}\text { UP: INHBE, IGFBP4, IGFBPI-IGFBP6 } \\
\text { DOWN: IGFI, TLLI }\end{array}$ \\
\hline 7 & Cell proliferation & 5.4 e-3 & $5 / 160$ & $\begin{array}{l}\text { UP: IGFBPI, IGFBP4, IGFBP6 } \\
\text { DOWN: IGFI, MMP2 }\end{array}$ \\
\hline 8 & Protein C signaling & 6.05 e-3 & $4 / 103$ & $\begin{array}{l}\text { UP: PLG, F9, FI0 } \\
\text { DOWN: EDG3 }\end{array}$ \\
\hline
\end{tabular}

*UP and DOWN refer to up-regulated and down-regulated, respectively. C2, complement c2; LGALS3BP, galectin-3-binding protein; MBL2, mannosebinding protein C; NOTCH, neurogenic locus notch homolog protein 2; TGFBI, transforming growth factor-beta-induced protein ig-h3.

metalloproteinase $2(\mathrm{MMP} 2)$ ) had an ERE in the downstream region of its corresponding gene.

\section{Validation of a set of proteins up-regulated with ET}

We sought to validate proteomic data by ELISA analysis of individual non-pooled sera from the same subjects in the study. Proteins were selected for assay among the set of 64 proteins meeting statistical criteria for change following CEE, based on availability of a pair of antibodies with the requisite specificity for ELISA-based validation. Thus, assays were available for IGF1, IGFBP4, IGFBP1, IGFBP6, F9, F10, AHSG, vitronectin (VTN), GC, CP, MMP2, kininogen (KNG1), and PROZ. In addition, IGFBP2 was tested as a negative control. SHBG was separately analyzed in a set of 50 women in the trial, who had similar characteristics to those in the training set. High-density lipoprotein and low-density lipoprotein were previously tested and, therefore, were not subjected to additional validation in our study [6]. Figure 3 presents the data at baseline and 1 year for each protein. The correlation between IPAS proteomic log-ratios and ELISA $\log$-ratios was strong (correlation $=0.83$ without SHBG and o.86 with SHGB; Figure 4). We obtained a correlation of 0.85 between spectral counts (number of tandem mass spectrometry (MS2) events/protein) and the known serum concentrations of more than 80 proteins (Figure $5 \mathrm{a}$ ). The measured abundance range of the proteins subjected to ELISA (Figure $5 \mathrm{~b}$ ) is indicative of the depth of proteomic analysis in this study, which was achieved through extensive fractionation of intact proteins and reliance on high-resolution MS, spanning seven logs of protein abundance. However, low abundance proteins are somewhat under-sampled, given that proteins quantified in more than two proteomic experiments only spanned some four logs of protein abundance.

\section{Validation studies in an independent set of sera}

We further analyzed an additional, independent validation set of 50 non-overlapping randomly selected women, who adhered to CEE over the first year of randomization in the CEE trial, for IGF1, IGFBP4, IGFBP1, F10, AHSG, GC, CP, MMP2, and PROZ and for IGFBP2 as a negative control (Figure 2). The correlation between ELISA results for the training set and the independent test set was 95\%, and between the independent set tested by ELISA and the training set tested by IPAS it was $87 \%$. Elevated concentrations at 1 year from randomization compared to baseline were observed in these independent samples for all ten proteins studied.

\section{Discussion}

The objective of this proteomic study was to determine whether an in-depth, unbiased, quantitative analysis of serum proteins in a clinical trial setting would uncover changes that are relevant to the objectives of the clinical trial, thereby supporting the utility of comprehensive 
Table 4

Classification of proteins with statistically significant changes based on Gene Ontology

\begin{tabular}{|c|c|c|}
\hline Protein & Log2 ratio year one relative to baseline & P-value \\
\hline \multicolumn{3}{|l|}{ Blood coagulation and inflammation } \\
\hline Vitronectin (VTN) & 0.374 & $9.27 \mathrm{E}-08$ \\
\hline Ceruloplasmin (CP) [59] & 0.789 & $1.5 \mathrm{IE}-06$ \\
\hline Plasminogen (PLG) [5I] & 0.307 & I.50E-06 \\
\hline Kininogen (KNGI) [52] & 0.265 & 2.89E-05 \\
\hline Coagulation factor XII (FI2) [52] & 0.364 & 4.64E-05 \\
\hline Coagulation factor IX (F9) & 0.558 & 8.34E-05 \\
\hline Coagulation factor X (FI0) & 0.332 & 0.00029 \\
\hline Carboxypeptidase N, polypeptide I (CPNI) & 0.288 & 0.0002 \\
\hline Platelet basic protein (PPBP) & 0.273 & 0.00363 \\
\hline Tissue factor pathway inhibitor (TFPI) [5I] & -0.267 & 0.01152 \\
\hline Fibrinogen gamma chain (FGG) & 0.273 & 0.01848 \\
\hline Matrix metalloproteinase 2 (MMP2) & -0.681 & 0.03019 \\
\hline Protein Z, vitamin K-dependent plasma glycoprotein (PROZ) & 0.676 & 0.03401 \\
\hline Hyaluronan-binding protein 2 (HABP2) & 0.324 & 0.00029 \\
\hline \multicolumn{3}{|l|}{ Metabolism } \\
\hline Sex hormone binding globulin (SHBG) [68] & 1.381 & 2.30E-07 \\
\hline Insulin-like growth factor binding protein I (IGFBPI) [18] & 1.318 & 3.82E-05 \\
\hline Insulin-like growth factor binding protein 4 (IGFBP4) [18] & 0.773 & 8.6IE-06 \\
\hline Apolipoprotein A-II (APOA2) [57] & 0.379 & 4.06E-06 \\
\hline Vitamin D binding protein (GC) [59] & 0.298 & $5.82 \mathrm{E}-06$ \\
\hline Apolipoprotein D (APOD) [57] & -0.396 & 0.00133 \\
\hline Insulin-like growth factor binding protein 6 (IGFBP6) & 0.303 & 0.00225 \\
\hline Insulin-like growth factor (IGFI) [I8] & -0.410 & 0.00366 \\
\hline Proprotein convertase subtilisin kexin 9 (PCSK9) & 0.385 & 0.02486 \\
\hline Serpin peptidase inhibitor, clade A, member 6 (SERPINA6) & 0.377 & 0.02446 \\
\hline \multicolumn{3}{|l|}{ Osteogenesis } \\
\hline Fetuin B (FETUB) & 0.748 & 2.8IE-07 \\
\hline Macrophage stimulating protein I (MSTI) & 0.546 & 0.00154 \\
\hline Collagen type I, alpha I (COLIAI) & -0.494 & 0.00023 \\
\hline Tolloid-like protein I, bone morphogenetic protein I (TLLI) & -1.150 & 0.0467 \\
\hline Neurogenic locus notch homolog protein $2(\mathrm{NOTCH} 2)$ & -0.289 & 0.01946 \\
\hline Neurogenic locus notch homolog protein 3 (NOTCH3) & -0.622 & 0.02133 \\
\hline Fetuin A (AHSG) [59] & 0.281 & I.16E-06 \\
\hline \multicolumn{3}{|l|}{ Cell growth } \\
\hline Inhibin, beta E (INHBE) & 0.472 & 0.01866 \\
\hline Follistatin-like 3 (FSTL3) & -0.353 & 0.02042 \\
\hline Transforming growth factor-beta-induced protein ig-h3 (TGFBI) & 0.322 & 0.0036 \\
\hline \multicolumn{3}{|l|}{ Complement and immune response } \\
\hline Serpin peptidase inhibitor, clade G, member I (SERPINGI) & 0.551 & 0.01216 \\
\hline Complement C2 (C2) & 0.333 & 0.00215 \\
\hline Complement factor H-related protein 5 (CFHL5) & 0.294 & $6.72 \mathrm{E}-05$ \\
\hline Complement factor B (BF) & 0.271 & $1.06 \mathrm{E}-06$ \\
\hline Pantetheinase (VNNI) & 0.564 & 0.00079 \\
\hline Leucine-rich alpha-2-glycoprotein (LRGI) & 0.539 & 0.00031 \\
\hline Neutrophil defensin I (DEFAI) & 0.303 & 0.00683 \\
\hline Mannose-binding protein C (MBL2) & -0.300 & 0.00094 \\
\hline TRAF-type zinc finger domain-containing protein I (TRAFDI) & -3.863 & 0.00762 \\
\hline Lactotransferrin (LTF) [69] & 0.285 & 0.04264 \\
\hline Trefoil factor 3 (TFF3) & 1.936 & 0.00019 \\
\hline \multicolumn{3}{|l|}{ Vessel morphogenesis } \\
\hline Autotaxin (ENPP2) & $0.58 \mathrm{I}$ & 0.00395 \\
\hline Vasorin (SLITL2) & -0.383 & 0.01997 \\
\hline Transgelin 2 (TAGLN2) & -0.542 & 0.01725 \\
\hline Endothelial differentiation G-protein coupled receptor 3 (EDG3) & -2.998 & 0.00033 \\
\hline Cardiomyopathy associated protein 5 (CMYA5) & -4.1374 & 0.01562 \\
\hline
\end{tabular}


Table 4 (continued)

\begin{tabular}{|c|c|c|}
\hline Protein & Log2 ratio year one relative to baseline & P-value \\
\hline \multicolumn{3}{|l|}{ Other } \\
\hline Angiotensinogen (AGT) $[15,16]$ & $\mathrm{I} .148$ & $7.16 \mathrm{E}-10$ \\
\hline Cathepsin S (CTSS) & 0.588 & 0.04665 \\
\hline Galectin-3-binding protein (LGALS3BP) & 0.416 & 0.00214 \\
\hline Galectin I (LGALSI) & 0.305 & 0.02924 \\
\hline E3 ubiquitin-protein ligase UBRI (UBRI) & -0.422 & 0.00511 \\
\hline Tropomyosin alpha-4 chain (TPM4) & -1.258 & 0.0269 \\
\hline DNA helicase B (HELB) & -1.862 & 0.02157 \\
\hline Putative Polycomb group protein ASXLI (ASXLI) & -2.658 & 0.02290 \\
\hline \multicolumn{3}{|l|}{ Protein CREG2 (CREG2) } \\
\hline Protein $\mathrm{RICI}$ homolog (KIAAI432) & -4.153 & 0.00155 \\
\hline Protein FAM59B (FAM59B) & -2.755 & 0.00119 \\
\hline $\mathrm{KH}$ homology domain-containing protein I (C6orfI48) & -3.060 & 0.00116 \\
\hline Alpha-IB-glycoprotein (AIBG) & 0.331 & I.82E-06 \\
\hline
\end{tabular}

Proteins with prior associations with ET are indicated with numbered references.

profiling of the serum proteome for clinical investigations. The choice of clinical trial for this study, namely the WHI CEE randomized controlled trial, is significant from the point of view of health effects observed, which include an adverse effect on stroke and venous thromboembolism and a reduction of hip fractures. Additionally, given that some findings have been published with respect to the effect of CEE on a selected set of serum proteins, there was an opportunity to assess concordance of proteomics-derived data with previously observed findings and to assess the potential of proteomics to uncover novel protein changes related to oral ET. We used acrylamide isotopic labeling of cysteine residues to obtain quantitative data for changes in serum proteins between baseline and 1 year after CEE for 50 subjects. This labeling approach is chemically very efficient as shown by the lack of unlabeled cysteines in searched mass spectra [19]. It would be expected given the number of proteins quantified that approximately 31 proteins would satisfy a nominal $P<0.05$ selection criterion under a global null hypothesis. The number of quantified proteins that reached this threshold of statistical significance was 116, which represented a sizeable fraction (19\%) of the proteins with quantitative measures and is indicative of a substantial effect of CEE on the serum proteome, based on a systematic, unbiased analysis.

It was of interest to determine the contribution of EREs to upregulation of protein levels with oral ET. The genes for four up-regulated proteins contained conserved EREs. LTF is a well known estrogen-regulated gene [37-40]. As with all classical estrogen target genes, the human and mouse orthologs of LTF both contain an ERE at a similar location in their promoter region, and are most sensitive to estrogen stimulation in the reproductive organs [39,40].The human $A G T$ gene includes an ERE close to the TATA box in its promoter region, which may be responsible for its increased transactivation by estrogen [41]. The $T F F 3$ gene, which plays a role in mucosal protection and repair in the gastro- intestinal tract, is known to be induced by estrogen [42], and it is over-expressed in several types of cancer [43]. Elevated serum levels of $\mathrm{TFF}_{3}$ have been reported in inflammatory bowel disease [44] and ulceration of the upper gastrointestinal tract [45]. LGALS1 was shown to be induced by estrogen [46]. One down-regulated protein (MMP2) had an ERE in the downstream region of the gene. In one study, estrogen was shown to increase MMP2 activity and protein expression in human granulosa lutein cells [47]. In another study, treatment with low dose estrogens increased MMP2 expression and activity. However, estrogens at a similar level as in the case of women receiving hormone replacement therapy failed to up-regulate MMP2 expression and activity [48]. The human MMP2 promoter contains several potential cis-acting regulatory elements, including cAMP response element-binding protein (CREB), AP-1, PEA3, C/EBP, $\mathrm{P}_{53}$, Est-1, AP-2, and Sp1 binding sites [49,50]. This may suggest that regulation of $M M P 2$ gene expression is not primarily through the classic ERE-mediated pathway [1]. Given that most up-regulated proteins with oral ET do not display a conserved ERE in their corresponding genes, it would follow that their upregulation is likely through other mechanisms.

Up-regulated serum levels were observed for as many as nine proteins that play a role in coagulation (PLG, F9, F10, factor XII (F12), KNG1, PROZ, SERPING1 (serpin peptidase inhibitor, clade G, member 1), VTN, and FGG (fibrinogen gamma chain)), which may be relevant to the increased risk of venous thromboembolism and stroke with CEE. Of these, PLG [51], FGG, F12, and high molecular weight KNG1 [52] have been reported to increase with ET. The last three of these are components of the plasma kallikrein-kinin system, which mediates changes in coagulation, inflammation and blood pressure, all of which may contribute to atherothrombosis. Increased levels of PROZ, F9, F10, VTN, FGG, and platelet basic protein (PPBP) are novel findings. PROZ is structurally related to F9 and F10, and serves as a cofactor for the inactivation of activated F10. A case-control study 


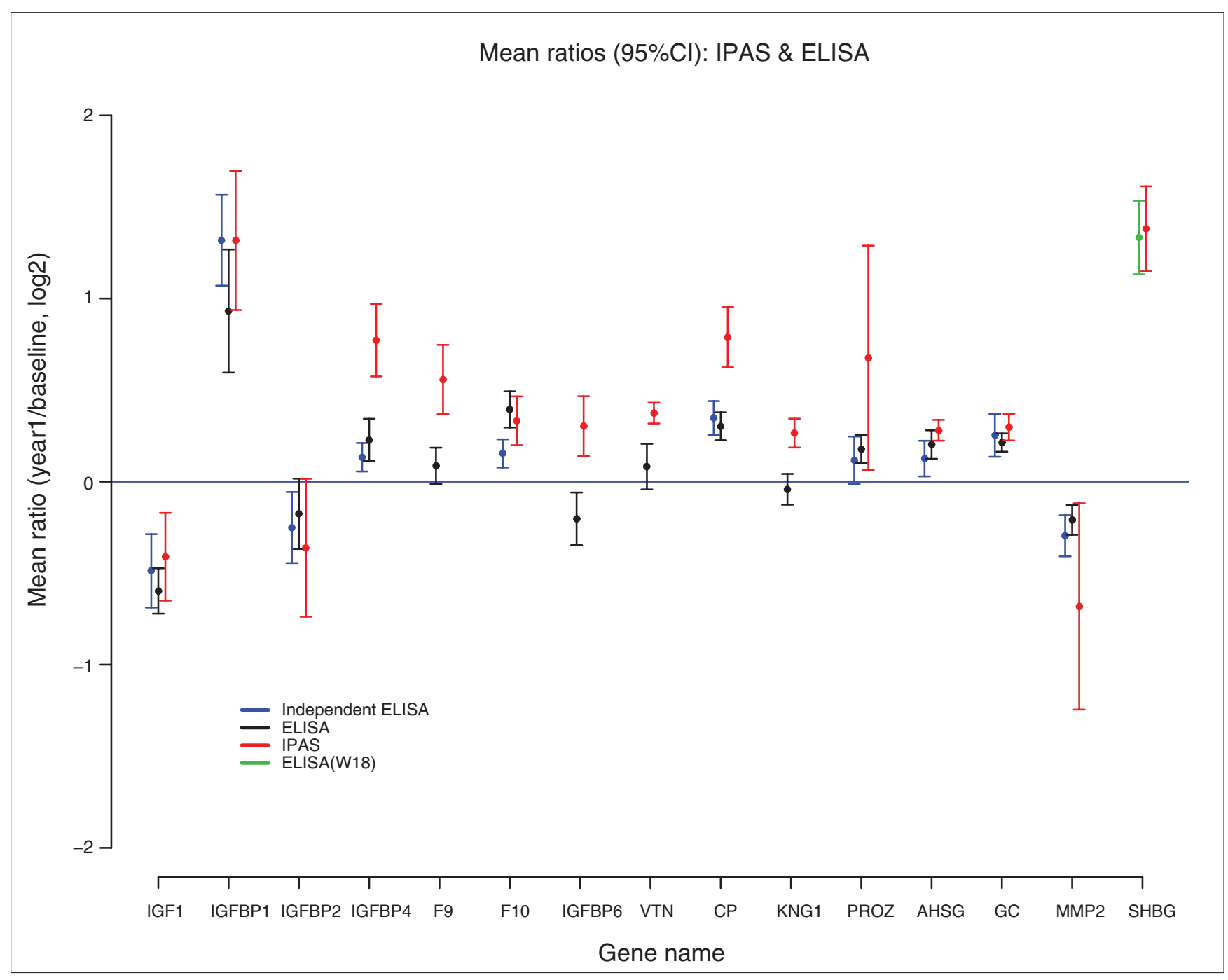

Figure 3

Mean ratios ( $95 \%$ confidence intervals (Cl)) for MS-based (IPAS, shown in red) and ELISA-based quantification (shown in black for the same set of 50 sera analyzed by MS and in blue for the independent set of 50 sera). SHBG ELISA data were based on a separate independent set of sera.

found a strong, independent relationship between elevated blood levels of PROZ and ischemic stroke during the acute phase [53]. Thus, our results are consistent with the notion that PROZ might be an important factor in the pathogenesis of ischemic stroke in postmenopausal women receiving CEE. Vascular smooth muscle cells constitutively elaborate the zymogen form of MMP2. When activated, MMP2 promotes vascular lesion development [54].

Our data indicate that IGF1/IGFBP levels were significantly changed after 1 year of $\mathrm{CEE}$, in accordance with data from a small randomized study of 35 healthy postmenopausal women in which circulating IGF1 levels were significantly reduced by CEE and plasma concentrations of IGFBP1 and IGFBP4 increased from baseline [18]. We confirmed in this larger study that CEE increased the IGFBP1 and IGFBP4 serum levels from baseline to 1 year of ET and decreased IGF1.

We observed for the first time CEE related increased levels of proprotein convertase subtilisin kexin 9 (PCSK9), which regulates low-density lipoprotein receptor levels. Mutations in the PCSK9 gene have been associated with CHD risk [55,56]. Our data confirm previously reported high levels of APOA2, a major component of high-density lipoprotein, with CEE [57]. We also found that SERPINA6 (serpin peptidase inhibitor, clade A, member 6), the major transporter for glucorticoids and progestins in the blood, is elevated after CEE. It has been negatively correlated with insulin resistance and body mass index [58]. Conversely, increased blood levels of GC [59] with CEE are associated with obesity and insulin resistance [6o]. Thus, through several pathways, 


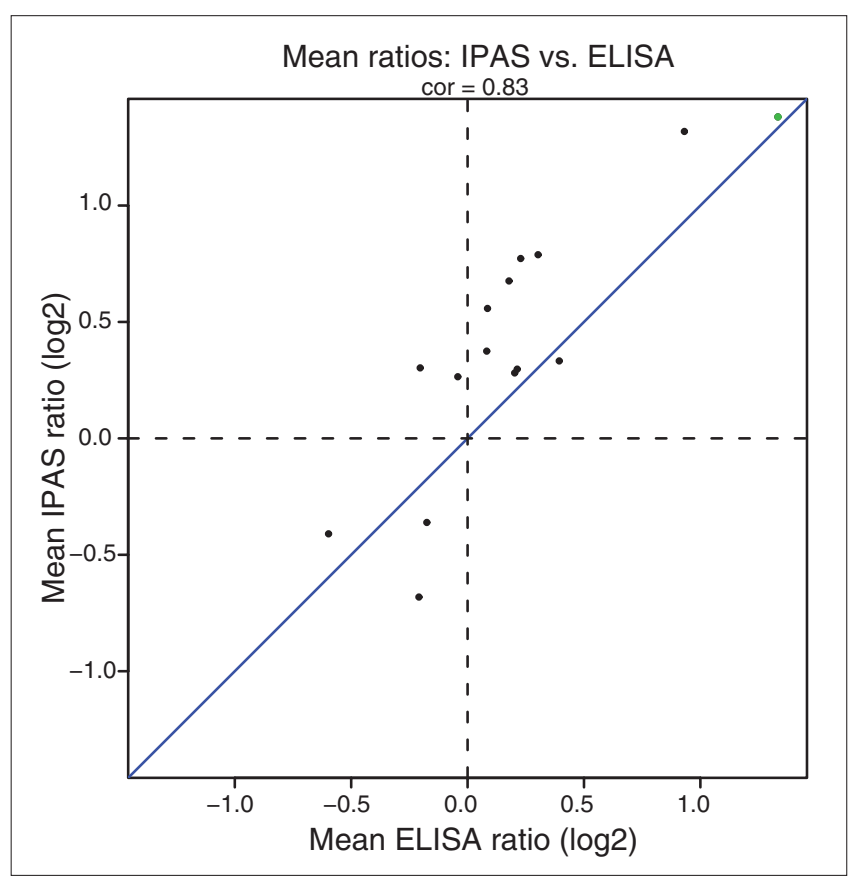

Figure 4

Comparison of mean ratios (I year ET/baseline) by IPAS MS and by ELISA.

estrogen appears to have effects on cardiovascular risk characteristics.

We found that several proteins from the inflammation, innate immunity and complement cascade were elevated after CEE, suggestive of a low grade inflammatory state, consistent with previously reported CEE-induced increases in C-reactive protein [14]. Some proteins implicated in cellular growth had increased levels with CEE (LTF, inhibin, beta E (INHBE), IGFBPs) whereas others were decreased (follistatin-like 3 (FSTL3), IGF1). Interestingly, we found changes in five proteins (AHSG, fetuin B (FETUB), macrophage stimulating protein 1 (MST1), collagen type 1, alpha 1 (COL1A), tolloidlike protein 1, bone morphogenetic protein 1 (TLL1)) directly implicated in osteogenesis and several others (IGF/IGFBPs, MMP2, NOTCH-1 and 3) that play a role in osteogenesis. These findings are of interest given the reduction in fractures with CEE.

AGT, a potent blood pressure vasoconstrictor, occurred at increased levels following CEE as previously observed $[15,16]$. Increases in levels of proteins from the plasma kallikrein-kinin system also suggest an impact of CEE on blood pressure regulation, although this has not been borne out in blood pressure measurements of women taking CEE.

Changes in levels of several proteins implicated in blood vessel morphogenesis and angiogenesis were observed. Autotaxin (ENPP2), an angiogenic factor and stimulant for cellular growth, was found to be increased whereas other proteins (transgelin 2 (TAGLN2), endothelial differentiation G-protein coupled receptor 3 (EDG3), cardiomyopathy associated protein 5 (CMYA5)) were decreased. MMP2, which promotes vascular lesion development [54], is decreased, as is SLITL2 (vasorin), which contributes to neointimal formation after arterial injury [61]. Changes in these proteins may have an effect on vasculature within 1 year of CEE.

Our proteomics study also confirmed that levels of lipoprotein APOA2, which is CHD protective, are up-regulated, while levels of APOD are down-regulated and apolipoprotein A (LPA) not changed, in accordance with previous findings from the WHI study [51]. The plasma kallikrein-kinin system has been implicated in cardiovascular disease in men, but activation of this system has not been specifically investigated in individuals at risk for CHD [62].

Reduction of hip fractures is a well known effect of CEE and, interestingly, we found that ossification was a major significant affected network. Changes in five proteins (AHSG, FETUB, MST1, COL1A, TLL1) directly implicated in osteogenesis were observed and several others (IGF/IGFBPs, MMP2, NOTCH-1) that play a role in osteogenesis exhibited altered levels with CEE.

To further support our proteomics findings, we measured by ELISA a subset of deregulated proteins using the same sera in our training set and in an additional validation set of 50 women. Our data showed a strong correlation between ELISA and MS results in both test and validation sets, reflecting reliability of MS and isotopic labeling for protein quantification. For the three proteins where ELISA measurements did not confirm the IPAS ratios, it is difficult to precisely determine the cause of the discrepancies. It is possible that different species are measured by ELISA versus IPAS (that is, different isoforms). Since the epitopes of the antibodies used in ELISAs are often not specified or ambiguous, it is difficult to conclusively determine if this is the case.

The findings presented here relate specifically to the effect on the serum proteome of orally administered postmenopausal ET. It is well know that the effect of estrogen depends on the route of administration $[63,64]$. For example, in one study, IGF-1 concentrations were found to decrease significantly with oral estrogen, whereas no significant change was observed with transdermal estrogen at 6 months [63]. Given the oral route of administration of estrogen in our study, it was of interest to determine the organ source of affected proteins. A search of gene expression data in SymAtlas [65] indicated that approximately half of the 62 proteins that were dysregulated with oral CEE in our study had the liver as their major organ source.

Protein changes after oral ET in postmenopausal women observed in this study indicate a substantial effect on 


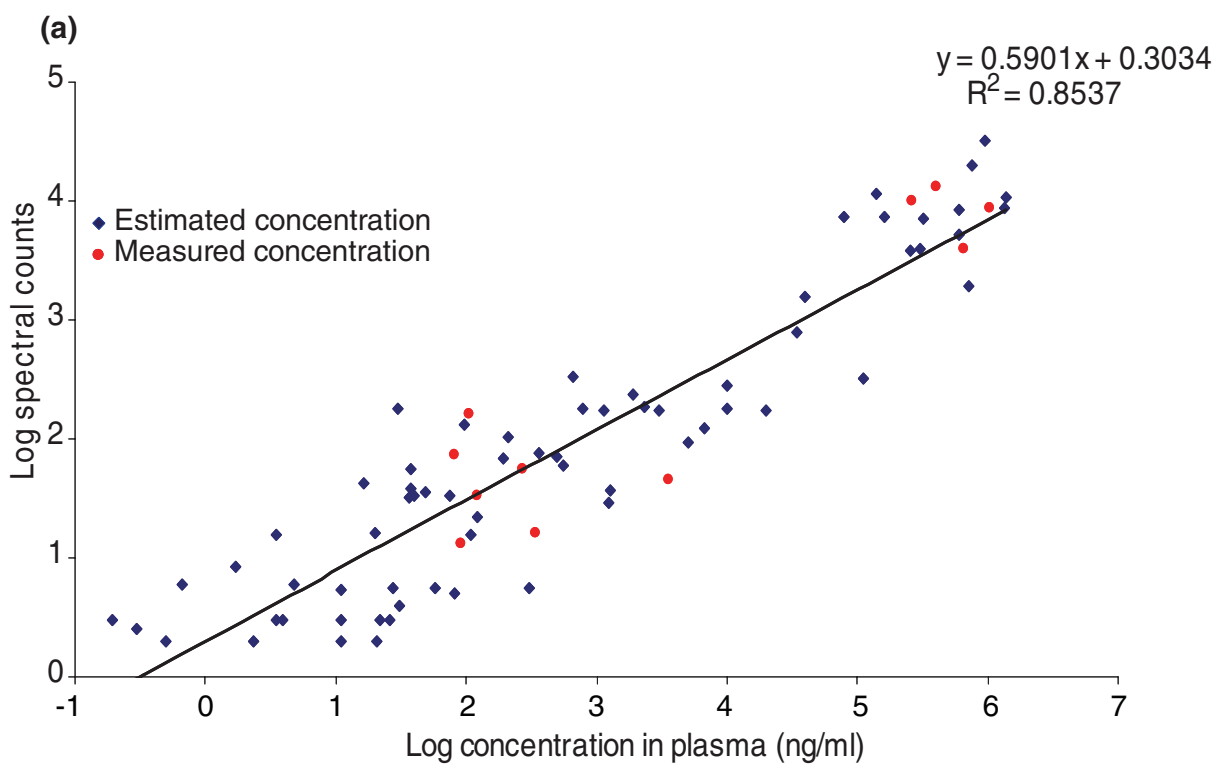

(b)

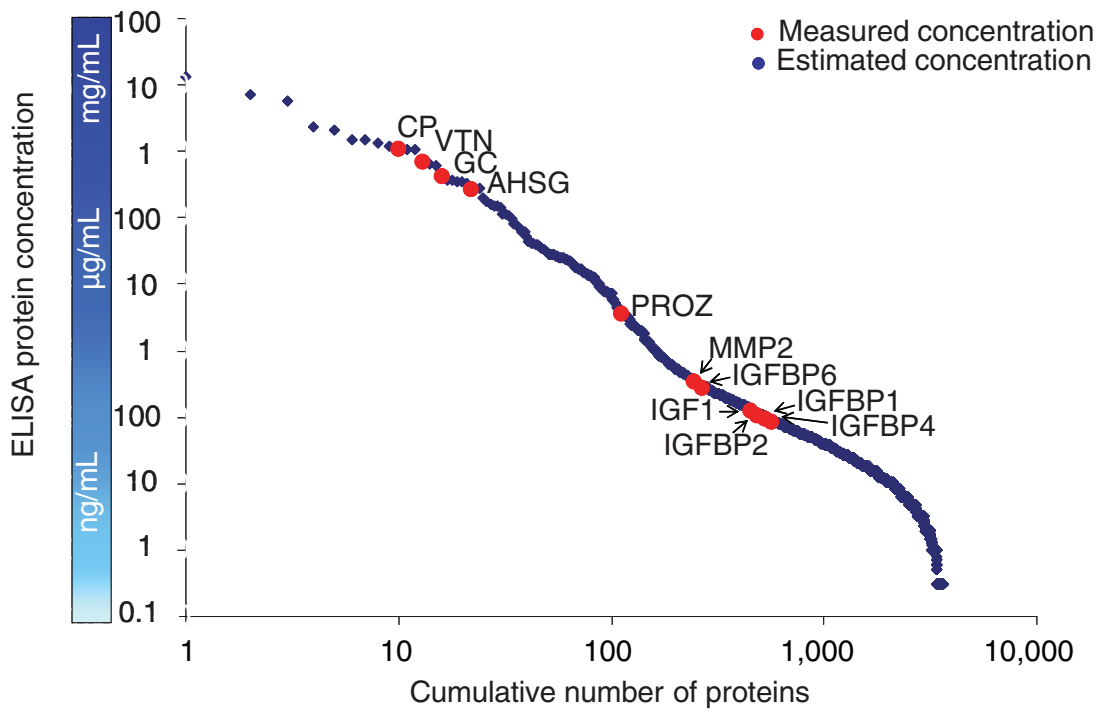

Figure 5

Dynamic range of IPAS MS pointing to proteins validated by ELISA. (a) Correlation between spectral counts (number of tandem mass spectra (MS2) acquired per protein) and estimated/measured serum concentrations. (b) Cumulative protein identifications are plotted versus ELISA protein concentration determined by ELISA measurments (red) and estimated concentration (blue) as determined by spectral counts.

coagulation and metabolic proteins that may explain the increased risk of venous thromboembolism and stroke and the reduced risk of fracture found in the WHI trial. Contributions of the route of administration of estrogen (oral versus transdermal) and dosage to effects on the serum proteome require further study, and our findings may not be directly relevant to parenteral routes of delivery or lower doses. We note that transdermal estrogen has not been linked to an increased risk of venous thromboembolism in a recent large meta-analysis [66].

\section{Conclusions}

In-depth proteomic MS analysis of plasmas obtained from subjects in the WHI hormone replacement therapy trial uncovered 116 proteins (19\%) that exhibited quantitative 
changes 1 year after CEE. Protein changes were related to processes that included coagulation, metabolism, osteogenesis, inflammation, and blood pressure maintenance. Findings for selected proteins were confirmed in the initial set of plasmas using ELISA, and further validated in an independent set of samples. This in-depth proteomic study has shown that a substantial fraction of the serum proteome is affected by CEE. The observed changes have relevance to findings from the clinical trial. This study points to the potential for proteomic investigations to provide a quantitative assessment of changes in the proteome that could elucidate effects of various interventions as part of clinical trials, and that form the basis of further investigations.

\section{Abbreviations}

AGT, angiotensinogen; AHSG, fetuin A; APOA2, apolipoprotein A-II; APOD, apolipoprotein D; CEE, conjugated equine estrogens; CHD, coronary heart disease; COL1A, collagen type 1, alpha 1; CP, ceruloplasmin; EDG3, endothelial differentiation G-protein coupled receptor 3; ELISA, enzyme-linked immunosorbent assay; ERE, estrogen response element; ET, estrogen therapy; F9, coagulation factor IX; F10, coagulation factors X; F12, coagulation factor XII; FDR, false discovery rate; FGG, fibrinogen gamma chain; GC, vitamin D binding protein; IGF, insulin-like growth factor; IGFBP, insulin-like growth factor binding protein; INHBE, inhibin, beta E; IPAS, intact protein analysis system; KNG1, kininogen; LGALS1, galectin-1; LTF, lactotransferrin; MMP2, matrix metalloproteinase 2; MS, mass spectrometry; MST1, macrophage stimulating protein 1; PCSK9, proprotein convertase subtilisin kexin 9; PLG, plasminogen; PROZ, protein Z, vitamin K-dependent plasma glycoprotein; SERPING1, serpin peptidase inhibitor, clade G, member 1; SHBG, sex hormone binding globulin; TFF3, trefoil factor 3; TLL1, tolloid-like protein 1, bone morphogenetic protein 1; VTN, vitronectin; WHI, Women's Health Initiative.

\section{Competing interests}

The authors declare that they have no competing interests.

\section{Authors' contributions}

HK participated in the data acquisition, analysis, and interpretation. SP contributed to data analysis and interpretation, and carried out immunoassays. RP participated in the design of the study, statistical analysis, and data interpretation, and drafted the manuscript. AA performed the statistical analysis. VMF and SJP participated in the data acquisition and interpretation. QZ participated in the data analysis. HW performed data acquisition. MS and JK carried out immunoassays. JR, RJ, JH, RC, and JM contributed to the drafting of the manuscript. SH participated in the study design, data interpretation, and drafting of the manuscript.

\section{Additional data files}

The following additional data are available with the online version of this paper. Additional data file 1 is an Excel document showing ratios (1 year CEE/baseline) of gene-level weighted proteins for each IPAS (log2scale), number of events identified for each unique gene and their $P$-values. Additional data file 2 is an Excel document showing weighted gene-level proteins quantified in two or more IPAS experiments with significant ratio 1 year ET/baseline $(P<0.05)$. Additional data file 3 is an Excel document showing proteins deregulated after 1 year ET with log-ratios $>1.20$ or $<1 / 1.20$.

\section{Acknowledgements}

This study was funded by the National Heart, Lung, and Blood Institute, National Institutes of Health, Department of Health and Human Services (contracts NOIWH22III0, 24I52, 32I00-2, 32I05-6, 32I08-9, 32III-I3, $32115,32118-19,32122,42107-26,42129-32$, and 44221). The active study drug and placebo were supplied by Wyeth-Ayerst Research Laboratories, Philadelphia, Pennsylvania. Dr Prentice's work was partially supported by grant CA53996 from the National Cancer Institute. Decisions concerning study design, data collection and analysis, interpretation of the results, the preparation of the manuscript, or the decision to submit the manuscript for publication resided with committees composed of WHI investigators that included NHLBI representatives. The authors thank the $\mathrm{WHI}$ investigators and staff for their outstanding dedication and commitment. A list of key investigators involved in this research follows. A full listing of WHI investigators can be found at the WHI website [67] Program Office: Elizabeth Nabel, Jacques Rossouw, Shari Ludlam, Linda Pottern, Joan McGowan, Leslie Ford, and Nancy Geller (National Heart, Lung, and Blood Institute, Bethesda, MD). Clinical Coordinating Center: Ross Prentice, Garnet Anderson, Andrea LaCroix, Charles L Kooperberg, Ruth E Patterson, Anne McTiernan (Fred Hutchinson Cancer Research Center, Seattle, WA); Sally Shumaker (Wake Forest University School of Medicine, Winston-Salem, NC); Evan Stein (Medical Research Labs, Highland Heights, KY); Steven Cummings (University of California at San Francisco, San Francisco, CA). Clinical Centers: Sylvia Wassertheil-Smoller (Albert Einstein College of Medicine, Bronx, NY); Aleksandar Rajkovic (Baylor College of Medicine, Houston, TX); JoAnn Manson (Brigham and Women's Hospital, Harvard Medical School, Boston, MA); Annlouise R Assaf (Brown University, Providence, RI); Lawrence Phillips (Emory University, Atlanta, GA); Shirley Beresford (Fred Hutchinson Cancer Research Center, Seattle, WA); Judith Hsia (George Washington University Medical Center, Washington, DC); Rowan Chlebowski (Los Angeles Biomedical Research Institute at Harbor- UCLA Medical Center, Tor rance, CA); Evelyn Whitlock (Kaiser Permanente Center for Health Research, Portland, OR); Bette Caan (Kaiser Permanente Division of Research, Oakland, CA); Jane Morley Kotchen (Medical College of Wisconsin, Milwaukee, WI); Barbara V Howard (MedStar Research Institute/Howard University, Washington, DC); Linda Van Horn (Northwestern University, Chicago/Evanston, IL); Henry Black (Rush Medical Center, Chicago, IL); Marcia L Stefanick (Stanford Prevention Research Center, Stanford, CA); Dorothy Lane (State University of New York at Stony Brook, Stony Brook, NY); Rebecca Jackson (The Ohio State University, Columbus, OH); Cora E Lewis (University of Alabama at Birmingham, Birmingham, AL); Tamsen Bassford (University of Arizona, Tucson/Phoenix, AZ); Jean Wactawski-Wende (University at Buffalo, Buffalo, NY); John Robbins (University of California at Davis, Sacramento, CA); F Allan Hubbell (University of California at Irvine, CA); Lauren Nathan (University of California at Los Angeles, Los Angeles, CA); Robert D Langer (University of California at San Diego, LaJolla/Chula Vista, CA); Margery Gass (University of Cincinnati, Cincinnati, OH); Marian Limacher (University of Florida, Gainesville/Jacksonville, FL); David Curb (University of Hawaii, Honolulu, HI); Robert Wallace (University of lowa, lowa City/Davenport, IA); Judith Ockene (University of Massachusetts/Fallon Clinic, Worcester, MA); Norman Lasser (University of Medicine and Dentistry of New Jersey, Newark, NJ); Mary Jo O'Sullivan (University of Miami, Miami, FL); Karen Margolis (University of Minnesota, Minneapolis, MN); Robert Brunner (University of Nevada, Reno, NV); Gerardo Heiss (University of North Carolina, Chapel Hill, NC); Lewis Kuller (University of Pittsburgh, Pittsburgh, PA); Karen C Johnson (University of Tennessee, Memphis, TN); Robert Brzyski (University of Texas Health Science 
Center, San Antonio, TX); Gloria E Sarto (University of Wisconsin, Madison, WI); Mara Vitolins (Wake Forest University School of Medicine, Winston-Salem, NC); Susan Hendrix (Wayne State University School of Medicine/Hutzel Hospital, Detroit, MI).

\section{References}

I. Marino M, Galluzzo P, Ascenzi P: Estrogen signaling multiple pathways to impact gene transcription. Curr Genomics 2006, 7:497-508.

2. Lobo RA: Estrogen and cardiovascular disease. Ann N Y Acad Sci 1990, 592:286-294; discussion 334-345.

3. Stampfer MJ, Colditz GA: Estrogen replacement therapy and coronary heart disease: a quantitative assessment of the epidemiologic evidence. Prev Med 1991, 20:47-63.

4. Anderson GL, Limacher $M$, Assaf AR, Bassford T, Beresford SA Black H, Bonds D, Brunner R, Brzyski R, Caan B, Chlebowski R, Curb D, Gass M, Hays J, Heiss G, Hendrix S, Howard BV, Hsia J, Hubbell $A$, Jackson R, Johnson KC, Judd $H$, Kotchen JM, Kuller $L$, LaCroix AZ, Lane D, Langer RD, Lasser N, Lewis CE, Manson J: Effects of conjugated equine estrogen in postmenopausal women with hysterectomy: the Women's Health Initiative randomized controlled trial. JAMA 2004, 29|: I70|-I7|2.

5. Stefanick ML, Anderson GL, Margolis KL, Hendrix SL, Rodabough RJ, Paskett ED, Lane DS, Hubbell FA, Assaf AR, Sarto GE, Schenken RS, Yasmeen S, Lessin L, Chlebowski RT: Effects of conjugated equine estrogens on breast cancer and mammography screening in postmenopausal women with hysterectomy. JAMA 2006, 295: I 647-I657.

6. Hsia J, Langer RD, Manson JE, Kuller L, Johnson KC, Hendrix SL, Pettinger M, Heckbert SR, Greep N, Crawford S, Eaton CB, Kostis JB, Caralis $P$, Prentice R: Conjugated equine estrogens and coronary heart disease: the Women's Health Initiative. Arch Intern Med 2006, 166:357-365

7. Manson JE, Allison MA, Rossouw JE, Carr J, Langer RD, Hsia J Kuller LH, Cochrane BB, Hunt JR, Ludlam SE, Pettinger MB, Gass M, Margolis KL, Nathan L, Ockene JK, Prentice RL, Robbins J, Stefanick ML: Estrogen therapy and coronary-artery calcification. N Engl J Med 2007, 356:259l-2602.

8. Rossouw JE, Prentice RL, Manson JE, Wu L, Barad D, Barnabei VM, Ko M, LaCroix AZ, Margolis KL, Stefanick ML: Postmenopausal hormone therapy and risk of cardiovascular disease by age and years since menopause. JAMA 2007, 297:|465-1477.

9. Brunner RL, Gass M, Aragaki A, Hays J, Granek I, Woods N, Mason E, Brzyski R, Ockene J, Assaf A, LaCroix A, Matthews K, Wallace R: Effects of conjugated equine estrogen on health-related quality of life in postmenopausal women with hysterectomy: results from the Women's Health Initiative Randomized Clinical Trial. Arch Intern Med 2005, 165:1976-1986.

10. Prentice RL, Anderson GL: The women's health initiative: lessons learned. Annu Rev Public Health 2008, 29: I3I-I 50.

II. Nelson HD, Humphrey LL, Nygren P, Teutsch SM, Allan JD: Postmenopausal hormone replacement therapy: scientific review. JAMA 2002, 288:872-881

12. Curb JD, Prentice RL, Bray PF, Langer RD, Van Horn L, Barnabei VM, Bloch MJ, Cyr MG, Gass M, Lepine L, Rodabough RJ, Sidney S, Uwaifo Gl, Rosendaal FR: Venous thrombosis and conjugated equine estrogen in women without a uterus. Arch Intern Med 2006, 166:772-780

13. Hendrix SL, Wassertheil-Smoller S, Johnson KC Howard BV, Kooperberg C, Rossouw JE, Trevisan M, Aragaki A, Baird AE, Bray PF, Buring JE, Criqui MH, Herrington D, Lynch JK, Rapp SR, Torner J: Effects of conjugated equine estrogen on stroke in the Women's Health Initiative. Circulation 2006, I 13:2425-2434.

14. Langer RD, Pradhan AD, Lewis CE, Manson JE, Rossouw JE, Hendrix SL, LaCroix AZ, Ridker PM: Baseline associations between postmenopausal hormone therapy and inflammatory, haemostatic, and lipid biomarkers of coronary heart disease. The Women's Health Initiative Observational Study. Thromb Haemost 2005, 93: I I 08-I I I 6.

15. Ichikawa J, Sumino H, Ichikawa S, Ozaki M: Different effects of transdermal and oral hormone replacement therapy on the reninangiotensin system, plasma bradykinin level, and blood pressure of normotensive postmenopausal women. Am J Hypertens 2006, 19:744-749.

16. Schunkert $H$, Danser $A H$, Hense HW, Derkx FH, Kurzinger S, Riegger GA: Effects of estrogen replacement therapy on the reninangiotensin system in postmenopausal women. Circulation 1997, 95:39-45.
I7. Andersson I, Aspergren K, Janzon L, Landberg T, Lindholm K, Linell $\mathrm{F}$, Ljungberg $\mathrm{O}$, Ranstam J, Sigfusson B: Mammographic screening and mortality from breast cancer: the Malmo mammographic screening trial. BMJ I 988, 297:943-948.

18. Heald A, Kaushal K, Anderson S, Redpath M, Durrington PN, Selby $\mathrm{PL}$, Gibson MJ: Effects of hormone replacement therapy on insulinlike growth factor (IGF)-I, IGF-II and IGF binding protein (IGFBP)-I to IGFBP-4: implications for cardiovascular risk. Gynecol Endocrinol 2005, 20:176-182.

19. Faca V, Coram M, Phanstiel D, Glukhova V, Zhang Q, Fitzgibbon M, Mclntosh M, Hanash S: Quantitative analysis of acrylamide labeled serum proteins by LC-MS/MS. J Proteome Res 2006, 5:2009-20I8.

20. Faca V, Pitteri SJ, Newcomb L, Glukhova V, Phanstiel D, Krasnoselsky A, Zhang Q, Struthers J, Wang H, Eng J, Fitzgibbon M, Mclntosh $\mathrm{M}$, Hanash S: Contribution of protein fractionation to depth of analysis of the serum and plasma proteomes. J Proteome Res 2007, 6:3558-3565.

21. Hanash SM, Pitteri SJ, Faca VM: Mining the plasma proteome for cancer biomarkers. Nature 2008, 452:571-579.

22. Faca VM, Song KS, Wang H, Zhang Q, Krasnoselsky AL, Newcomb LF, Plentz RR, Gurumurthy S, Redston MS, Pitteri S], Pereira-Faca SR, Ireton RC, Katayama H, Glukhova V, Phanstiel D, Brenner DE Anderson MA, Misek D, Scholler N, Urban ND, Barnett MJ, Edelstein C, Goodman GE, Thornquist MD, Mclntosh MW, DePinho RA Bardeesy N, Hanash SM: A mouse to human search for plasma proteome changes associated with pancreatic tumor development. PLOS Med 2008, 5:el 23.

23. Gericke B, Koebnick C, Reimann M, Forterre S, Franz Zunft HJ, Schweigert FJ: Influence of hormone replacement therapy on proteomic pattern in serum of postmenopausal women. Maturitas 2005, 51:334-342.

24. Pitteri SJ, Faca VM, Kelly-Spratt KS, Kasarda AE, Wang H, Zhang Q, Newcomb L, Krasnoselesky A, Paczesny S, Choi G, Fitzgibbon M, Mclntosh MW, Kemp CJ, Hanash SM: Plasma proteome profiling of a mouse model of breast cancer identifies a set of up-regulated proteins in common with human breast cancer cells. J Proteome Res 2008, 7:|48|-|489.

25. Rauch A, Bellew M, Eng J, Fitzgibbon M, Holzman T, Hussey P, Igra M, Maclean B, Lin CW, Detter A, Fang R, Faca V, Gafken P, Zhang H, Whiteaker J, States D, Hanash S, Paulovich A, Mclntosh MW: Computational Proteomics Analysis System (CPAS): an extensible, opensource analytic system for evaluating and publishing proteomic data and high throughput biological experiments. J Proteome Res 2006 5:II2-12I.

26. Keller A, Nesvizhskii Al, Kolker E, Aebersold R: Empirical statistical model to estimate the accuracy of peptide identifications made by MS/MS and database search. Anal Chem 2002, 74:5383-5392.

27. Nesvizhskii Al, Keller A, Kolker E, Aebersold R: A statistical model for identifying proteins by tandem mass spectrometry. Anal Chem 2003, 75:4646-4658

28. R Development Core Team: $\mathbf{R} A$ language and environment for statistical computing. In $R$ Foundation for Statistical Computing. Vienna, Austria; 2007.

29. Smyth GK: Linear models and empirical bayes methods for assessing differential expression in microarray experiments. Stat Appl Genet Mol Biol 2004, 3:Article3.

30. Smyth GK: Limma: linear models for microarray data. In Bioinformatics and Computational Biology Solutions using $R$ and Bioconductor. Edited by Gentleman R, Carey V, Dudoit S, Irizarry R, Huber W. New York: Springer; 2005:397-420

31. Benjamini $Y$, Hochberg Y: Controlling false discovery rate: a practical and powerful approach to multiple testing. J Roy Stat Soc 1995, 57:289-300.

32. Nikolsky Y, Ekins S, Nikolskaya T, Bugrim A: A novel method for generation of signature networks as biomarkers from complex high throughput data. Toxicol Lett 2005, 158:20-29.

33. Jarvinen AK, Autio $R$, Haapa-Paananen $S$, Wolf $M$, Saarela $M$, Grenman R, Leivo I, Kallioniemi O, Makitie AA, Monni O: Identification of target genes in laryngeal squamous cell carcinoma by high-resolution copy number and gene expression microarray analyses. Oncogene 2006, 25:6997-7008.

34. Lee TL, Alba D, Baxendale V, Rennert OM, Chan WY: Application of transcriptional and biological network analyses in mouse germ-cell transcriptomes. Genomics 2006, 88:18-33.

35. Vogelstein B, Kinzler KW: Cancer genes and the pathways they control. Nat Med 2004, 10:789-799. 
36. Bourdeau V, Deschenes J, Metivier R, Nagai Y, Nguyen D, Bretschnei$\operatorname{der}$ N, Gannon F, White JH, Mader S: Genome-wide identification of high-affinity estrogen response elements in human and mouse. Mol Endocrinol 2004, | 8: | 4 | | - | 427.

37. Pentecost BT, Teng CT: Lactotransferrin is the major estrogen inducible protein of mouse uterine secretions. J Biol Chem 1987, 262:10134-10139.

38. Teng CT, Walker MP, Bhattacharyya SN, Klapper DG, DiAugustine RP, McLachlan JA: Purification and properties of an oestrogen-stimulated mouse uterine glycoprotein (approx. 70 kDa). Biochem J 1986 , 240:4I3-422.

39. Teng $C T$ : Lactoferrin gene expression and regulation: an overview. Biochem Cell Biol 2002, 80:7-16.

40. Teng CT: Factors regulating lactoferrin gene expression. Biochem Cell Biol 2006, 84:263-267.

4I. Zhao YY, Zhou J, Narayanan CS, Cui Y, Kumar A: Role of C/A polymorphism at $-\mathbf{2 0}$ on the expression of human angiotensinogen gene. Hypertension 1999, 33:108-II5.

42. May FE, Westley BR: Expression of human intestinal trefoil factor in malignant cells and its regulation by oestrogen in breast cancer cells. J Pathol 1997, I82:404-4I3.

43. GeneCards: TFF3 Gene [http://www.genecards.org/cgi-bin/carddisp.pl?gene $=$ TFF3\&search $=$ tff3]

44. Gronbaek H, Vestergaard EM, Hey H, Nielsen JN, Nexo E: Serum trefoil factors in patients with inflammatory bowel disease. Digestion 2006, 74:33-39.

45. Vestergaard EM, Poulsen SS, Gronbaek H, Larsen R, Nielsen AM, Ejskjaer K, Clausen JT, Thim L, Nexo E: Development and evaluation of an ELISA for human trefoil factor 3. Clin Chem 2002, 48:16891695.

46. Westley B, Rochefort H: A secreted glycoprotein induced by estrogen in human breast cancer cell lines. Cell 1980, 20:353-362.

47. Puistola U, Westerlund A, Kauppila A, Turpeenniemi-Hujanen T: Regulation of 72-kd type IV collagenase-matrix metalloproteinase-2 by estradiol and gonadotropin-releasing hormone agonist in human granulosa-lutein cells. Fertil Steril 1995, 64:8I-87.

48. Marin-Castano ME, Elliot SJ, Potier M, Karl M, Striker LJ, Striker GE, Csaky KG, Cousins SW: Regulation of estrogen receptors and MMP2 expression by estrogens in human retinal pigment epithelium. Invest Ophthalmol Vis Sci 2003, 44:50-59.

49. Qin H, Sun Y, Benveniste EN: The transcription factors SpI, Sp3, and AP-2 are required for constitutive matrix metalloproteinase-2 gene expression in astroglioma cells. J Biol Chem 1999, 274:29130-29137.

50. Bian J, Sun Y: Transcriptional activation by $\mathrm{p} 53$ of the human type IV collagenase (gelatinase A or matrix metalloproteinase 2 ) promoter. Mol Cell Biol 1997, 17:6330-6338.

5I. Kooperberg C, Cushman M, Hsia J, Robinson JG, Aragaki AK, Lynch JK, Baird AE, Johnson KC, Kuller LH, Beresford SA, Rodriguez B: Can biomarkers identify women at increased stroke risk? The Women's Health Initiative Hormone Trials. PLoS Clin Trials 2007 2:e28.

52. Fossum S, Hoem NO, Gjonnaess H, Briseid K: Contact activation factors in plasma from women on estrogen replacement therapy after ovariohysterectomy. Thromb Res 1999, 93:161-170.

53. McQuillan AM, Eikelboom JW, Hankey GJ, Baker R, Thom J, Staton J, Yi Q, Cole V: Protein Z in ischemic stroke and its etiologic subtypes. Stroke 2003, 34:24I5-24I9.

54. Galis ZS, Kranzhofer R, Fenton JW 2nd, Libby P: Thrombin promotes activation of matrix metalloproteinase-2 produced by cultured vascular smooth muscle cells. Arterioscler Thromb Vasc Biol 1997, 17:483-489.
55. Humphries SE, Whittall RA, Hubbart CS, Maplebeck S, Cooper JA Soutar AK, Naoumova R, Thompson GR, Seed M, Durrington PN, Miller JP, Betteridge DJ, Neil HA: Genetic causes of familial hypercholesterolaemia in patients in the UK: relation to plasma lipid levels and coronary heart disease risk. J Med Genet 2006, 43:943-949.

56. Abifadel M, Varret M, Rabes JP, Allard D, Ouguerram K, Devillers M, Cruaud C, Benjannet S, Wickham L, Erlich D, Derre A, Villeger L, Farnier M, Beucler I, Bruckert E, Chambaz J, Chanu B, Lecerf JM, Luc G, Moulin P, Weissenbach J, Prat A, Krempf M, Junien C, Seidah NG, Boileau C: Mutations in PCSK9 cause autosomal dominant hypercholesterolemia. Nat Genet 2003, 34: I54-I56.

57. Wallentin L, Larsson-Cohn U: Metabolic and hormonal effects of post-menopausal oestrogen replacement treatment. II. Plasma lipids. Acta Endocrinol 1977, 86:597-607.

58. Fernandez-Real JM, Pugeat M, Grasa M, Broch M, Vendrell J, Brun J Ricart W: Serum corticosteroid-binding globulin concentration and insulin resistance syndrome: a population study. J Clin Endocrino Metab 2002, 87:4686-4690.

59. Hashimoto S, Miwa M, Akasofu K, Nishida E: Changes in 40 serum proteins of post-menopausal women. Maturitas I99I, I3:23-33.

60. lyengar S, Hamman RF, Marshall JA, Majumder PP, Ferrell RE: On the role of vitamin $D$ binding globulin in glucose homeostasis: results from the San Luis Valley Diabetes Study. Genet Epidemiol 1989, 6:691-698.

6I. Ikeda Y, Imai Y, Kumagai H, Nosaka T, Morikawa Y, Hisaoka T, Manabe I, Maemura K, Nakaoka T, Imamura T, Miyazono K, Komuro I, Nagai R, Kitamura T: Vasorin, a transforming growth factor betabinding protein expressed in vascular smooth muscle cells, modulates the arterial response to injury in vivo. Proc Natl Acad Sci USA 2004, I0I: 10732-10737.

62. Govers-Riemslag JW, Smid M, Cooper JA, Bauer KA, Rosenberg RD, Hack CE, Hamulyak K, Spronk HM, Miller G], ten Cate H: The plasma kallikrein-kinin system and risk of cardiovascular disease in men. J Thromb Haemost 2007, 5: I896-1903.

63. Sonnet E, Lacut K, Roudaut N, Mottier D, Kerlan V, Oger E: Effects of the route of oestrogen administration on IGF-I and IGFBP-3 in healthy postmenopausal women: results from a randomized placebocontrolled study. Clin Endocrinol (Oxf) 2007, 66:626-63I.

64. Taskinen MR, Puolakka J, Pyorala T, Luotola H, Bjaorn M, Kaarianen J, Lahdenpera S, Ehnholm C: Hormone replacement therapy lowers plasma Lp(a) concentrations. Comparison of cyclic transdermal and continuous estrogen-progestin regimens. Arterioscler Thromb Vasc Biol 1996, 16:1215-1221.

65. SymAtlas [http://symatlas.gnf.org]

66. Canonico M, Plu-Bureau G, Lowe GD, Scarabin PY: Hormone replacement therapy and risk of venous thromboembolism in postmenopausal women: systematic review and meta-analysis. Bmj 2008, 336:I227-123I.

67. WHI Participant Website [http://www.whi.org]

68. Helgason S, Damber JE, Damber MG, von Schoultz B, Selstam G, Sodergard R: A comparative longitudinal study on sex hormone binding globulin capacity during estrogen replacement therapy. Acta Obstet Gynecol Scand 1982, 61:97-100.

69. Kelver ME, Kaul A, Nowicki B, Findley WE, Hutchens TW, Nagaman $M$ : Estrogen regulation of lactoferrin expression in human endometrium. Am J Reprod Immunol 1996, 36:243-247. 